\title{
Bruce D. Browner, Jesse B. Jupiter, Alan M. Levine, Peter G. Trafton, Christian Krettek (eds): Skeletal trauma basic science, management, and reconstruction fourth edition + DVD
}

\author{
Saunders Elsevier, Philadelphia, 2009, Volumes 1 \& 2, 2882 pp and Index 156 pp, \\ number of figures, Hardcover 429,00 US \$, ISBN 978-1416022206
}

Pierre Kehr

Received: 1 May 2010/Accepted: 5 May 2010/Published online: 19 May 2010

(C) Springer-Verlag 2010

This book in two volumes and almost 3,000 pages may be considered as a bible on skeletal trauma surgery. Indeed, the 65 chapters of this book offer an exhaustive view of all the skeletal traumas of the body. It is not only a simple technical book. Depending on type of trauma, the chapters include a special section on anatomy, biomechanics, radiographic evaluation, physical examination, and of course, treatments and indications.

It is perfectly illustrated with very clear drawings, X-rays and per-operative shots. Post-operative care, complications and outcome are also addressed. The different chapters are easy to read and very didactic.
This book is really indispensable to surgeons who have a trauma activity and also to residents who want to be trauma surgeon and to trauma departments.

A very complete and useful index is proposed at the end of the book. Of course, a DVD is included.

Pr. Didier Mainard

Nancy

No funds were received in support of this study.
P. Kehr $(\bowtie)$

SOTEST, Strasbourg, France

e-mail: kehrpier@aol.com 